STEPHAN GOLLASCH, Ph.D.

E-mail: sgollasch@aol.com

GoConsult

Grosse Brunnenstrasse 61, 22763 Hamburg, Germany

MATEJ DAVID, Ph.D.

E-mail: matej.david@fpp.uni-lj.si

University of Ljubljana,

Faculty of Maritime Studies and Transport

Pot pomorščakov 4, 6320 Portorož, Slovenia
Traffic and Environment (Ecology)

Review

Accepted: Sep. 6, 2010

Approved: July 6, 2011

\title{
SAMPLING METHODOLOGIES AND APPROACHES FOR BALLAST WATER MANAGEMENT COMPLIANCE MONITORING
}

\begin{abstract}
The human-mediated transfer of harmful organisms via shipping, especially via ballast water transport, has raised considerable attention especially in the last decade due to the negative associated impacts. Ballast water sampling is important to assess the compliance with ballast water management requirements (i.e. compliance monitoring). The complexity of ballast water sampling is a result of organism diversity and behaviour which may require different sampling strategies, as well as ship design implications including availability of ballast water sampling points. This paper discusses the ballast water sampling methodologies with emphasis on compliance monitoring by the Port State Control officers according to the International Convention on the Management of Ships' Ballast Water and Sediments, 2004.
\end{abstract}

\section{KEY WORDS}

maritime transport, compliance control, port state control, ballast water sampling, ballast water management

\section{INTRODUCTION}

Shipping studies conducted since the early 1980s around the world have shown that living organisms are present in ballast water and related sediments [1-8] as well as in ship's hull fouling [9-11]. Most ballast water sampling programs also showed the occurrence of non-indigenous, harmful and/or pathogenic organisms, including human pathogens [2, 3, 12-18]. Estimations result in approximately 2.2 [19] to 12 billion tonnes of ballast water being transported across the world oceans annually [20], transferring some 7,000 species in ballast water daily [21]. In a summary of 15 European sampling studies more than 1,000 living species were found in ballast tanks of vessels arriving in European ports [22].

Where released, the non-indigenous, harmful and/ or pathogenic organisms may survive and establish in the new environment and have the potential to cause serious harm to human health, ecosystems or economy [15, 23, 24]. Just a few non-indigenous species have had significant (almost catastrophic) and seemingly irreversible impacts $[25,26]$. Hence, a precautionary approach assumes that every vessel transporting ballast water should be treated as a potential vector for species introductions.

Ballast water sampling is critical to assess the risks posed by unmanaged ballast water releases and also to verify the efficacy of applied management measures. The variability of organism type, size and behaviour; the complexity of physical and chemical characteristics in ballast water and sediments imposes the use of a variety of sampling methods $[3,7,14,16-18$, 27-38].

All ballast water sampling studies concluded that sampling onboard ships requires a different strategy compared to sampling in the natural environment, especially noting that sampling access is not easily available. Since vessels do not have dedicated ballast water sampling points, ballast water needs to be sampled by available access points. Most of the sampling equipment used in the past ballast water studies was not designed for the purpose of vessel sampling resulting in various limitations. Further, the sampling access points are highly variable between ships [31, 32, 36, 37].

Every sampling method has its advantages and shortcomings. Little attention has yet been paid with regard to the comparative analysis of the effectiveness of various detection strategies for ballast water organisms. Sampling methods of ballast water are far from being adequately tested and it remains therefore unclear how representative the sampling results are. Especially in compliance monitoring with the standards set forth in the International Convention on the Management of Ships' Ballast Water and Sediments 
(BWM Convention) representativeness is a key feature as non-compliance may have legal implications.

\section{MATERIAL AND METHODS}

The research projects considered here consisted of practical studies in which ballast water was sampled from ships' ballast tanks. During these studies more than 1,200 ballast water samples were taken on more than 550 vessels of various types ranging from small cargo vessels with deadweight (DWT) of $<1,000$ tons to Very Large Crude Carriers (VLCCs) of $>300,000$ tons [22, 38].

The sampling methods developed during the previously undertaken ballast water studies were consulted with an emphasis on how the ballast water was accessed. During these studies the ballast water samples were taken using a variety of nets, hoses and pumps operated via tank openings (manholes), pumps operated via sounding pipes, air vents or the seawaterconnected fire-fighting system and by extracting water at the ships` ballast pump (in-line sampling).

For this contribution it was of prime importance to consider the appropriate sampling approach for compliance control according to the BWM Convention, rather than the method details, thereby ignoring the sampling tool specifics, such as mesh size, net diameter, pump capacity etc. which was already published elsewhere [32, 36, 37, 40].

Different aspects of ballast water sampling in the framework of the BWM Convention were put in focus, since this is a globally concerted tool for the required compliance monitoring to assess whether or not ships are in line with the acceptable organisms concentrations during the ballast water discharge. Consequently, the ballast water working group of the International Maritime Organization (IMO) developed a sampling guideline, i.e. Guidelines for Ballast Water Sampling (G2) [41], which was also considered in this contribution. Additional insights were gained from the authors' involvement in different national and international research studies [7, 31, 36, 37], expert, scientific and/ or governmental working groups or organisations (i.e. ICES/IOC/IMO Working Group on Ballast and Other Ship Vectors, Trilateral Ballast Water Management Sub Commission, IMO/MEPC/Ballast Water Working Group, Global Ballast Water Management Programme of IMO, the European Maritime Safety Agency and the relevant national authorities) where different aspects (i.e. biological, technical, logistical) of ballast water sampling were addressed.

\section{RESULTS}

\subsection{Sampling methods according to the access point}

The sampling points may be divided into in-tank and at-discharge sampling points. In-tank sampling points enable ballast water access directly from a tank either via ballast tank manholes, sounding or air pipes. At-discharge sampling points include the ship's pipe-work at or after the ships ballast water pumps, at the fire-fighting system or at discharge openings.

\subsection{Compliance control sampling}

After entry into force of the BWM Convention IMO Member States will be required to check vessels for compliance with the standards of the BWM Convention, and this will be done also by sampling ballast water on vessels. In accordance with Article 9.1, ships to which the Convention applies may be subject to inspections for the purpose of revealing violations of the provisions of the Convention. These inspections shall:

- verify that the ship is carrying a valid Ballast Water Management Certificate;

- verify that a Ballast Water Management Plan specific to the ship and approved by the Flag State is onboard;

- undertake an inspection of the Ballast Water Record Book.

As part of the Port State Control efforts and to demonstrate compliance with the BWM Convention Standards, the port authorities may consider sampling ballast water for subsequent analyses. The sampling guidance provided by IMO as in the Guidelines for Ballast Water Sampling (G2) is based mainly on general information. Here we focus on the selection of appropriate sampling methodologies to assess compliance with the IMO ballast water standards. Two standards are of particular relevance, i.e. the ballast water exchange (Regulation D-1) and performance (Regulation D-2) standard.

The BWM Convention in the Regulation D-1, the Ballast Water Exchange Standard, states:

1 - Ships performing Ballast Water exchange in accordance with this regulation shall do so with an efficiency of at least 95 percent volumetric exchange of Ballast Water.

2 - For ships exchanging Ballast Water by the pumping-through method, pumping through three times the volume of each Ballast Water tank shall be considered to meet the standard described in paragraph 1. Pumping through less than three times the volume may be accepted provided the ship can demonstrate that at least 95 percent volumetric exchange is met. 
Further requirements regarding ballast water exchange are given in Regulation B-4.

1 - A ship conducting Ballast Water exchange to meet the standard in regulation D-1 shall:

1 whenever possible, conduct such Ballast Water exchange at least 200 nautical miles from the nearest land and in water at least 200 metres in depth, taking into account the Guidelines developed by the Organization;

.2 in cases where the ship is unable to conduct Ballast Water exchange in accordance with paragraph 1.1, such Ballast Water exchange shall be conducted taking into account the Guidelines described in paragraph 1.1 and as far from the nearest land as possible, and in all cases at least 50 nautical miles from the nearest land and in water at least 200 metres in depth.

2 - In sea areas where the distance from the nearest land or the depth do not meet the parameters described in paragraphs 1.1 or 1.2, the port State may designate areas, in consultation with adjacent or other States, as appropriate, where a ship may conduct Ballast Water exchange, taking into account the Guidelines described in paragraph 1.1.

In Regulation D-2, the ballast water Performance Standard is outlined:

1 - Ships conducting Ballast Water Management in accordance with this regulation shall discharge less than 10 viable organisms per $\mathrm{m}^{3}$ greater than or equal to $50 \mu \mathrm{m}$ in minimum dimension and less than 10 viable organisms per $\mathrm{ml}$ less than $50 \mu \mathrm{m}$ in minimum dimension and greater than or equal to $10 \mu \mathrm{m}$ in minimum dimension; and discharge of the indicator microbes shall not exceed the specified concentrations described in paragraph 2 .

2 - Indicator microbes, as human health standard, shall include:

.1 Toxicogenic Vibrio cholerae (01 and 0139) with less than 1 colony forming unit (cfu) per $100 \mathrm{ml}$ or less than 1 cfu per $1 \mathrm{~g}$ (wet weight) zooplankton samples;

.2 Escherichia coli less than 250 cfu per $100 \mathrm{ml}$;

3 Intestinal Enterococci less than 100 cfu per 100 $\mathrm{ml}$.

Unlike sampling for approval of ballast water treatment systems, which need to meet the abovementioned D-2 standard, sampling for compliance control is required to identify any possible non-compliance with D-2. At present the D-2 standard can be interpreted either as an instantaneous standard (i.e. the standard applies to any water volume discharged) or as an average standard (i.e. the standard applies to the total discharge amount). This is of key importance as results of sample analysis will have operational and legal implications in cases of non-compliance.

If the sampling must demonstrate compliance with the D-2 standard, then documenting the number of or- ganisms above $50 \mu \mathrm{m}$ in minimum dimension is especially challenging since less than 10 viable organisms per $\mathrm{m}^{3}$ of water are acceptable. Various difficulties can be identified such as more than 1,000 I of water may need to be collected to prove compliance, and several replicates need to be sampled to meet general scientific standards and accuracy. To meet these requirements new sampling techniques are currently developing. These technologies are specially designed for the purpose of ballast water sampling and may be easier for use onboard vessels compared to standard plankton sampling technologies.

The accuracy of the sampling technique must be determined; inefficient sampling techniques may result in false negatives as a result of missing organisms. The most representative samples may be taken when the ballast water is sampled over the entire discharge time of a ballast tank due to the heterogeneous nature of the species distributions in the tank [42]. Unfortunately, this can be unfeasible due to logistical/practical constraints. On large bulkers a complete discharge of the ballast water may take several days and will also not be continuous, but interrupted according to the cargo operations demand. An onboard sampling study has shown that organism survival is negatively impacted during longer sampling times and also when larger water volumes are concentrated (crowding effect) [43].

\subsubsection{Recommendations for compliance control samplings with the Ballast Water Exchange Standard (D-1)}

To prove that the ballast water was exchanged, the compliance control methods by sampling are minimal. The salinity values verify if the water has been exchanged according to the BWM Convention requirements (i.e. in cases where the salinity is low, e.g. below $30 \mathrm{psu}$ ) it can be assumed that the ballast water originates from coastal areas with freshwater influence, i.e. it was not exchanged as ocean water (i.e. outside 50 or 200nm from nearest shore and at water depths of more than $200 \mathrm{~m}$ ) would have higher salinity. For this purpose, small quantities of ballast water may directly be sampled from the tank via sounding pipes or manholes prior to its discharge. However, this is a feasible option only when the inspected vessel has loaded ballast in a low salinity or freshwater port.

Biological sampling for D-1 control is also of a limited value as very few organisms are restricted in their distribution to coastal waters. Candidate organism groups include harpacticoid copepods and barnacles. Barnacles, however, are frequently found on vessels and in the unlikely event that two vessels follow each other at close distance the barnacles on the preceding vessel may release their larvae into the water and they may be pumped in during the ballast water exchange 
operation of the second vessel sailing right behind the first. As a result, the exchanged ballast water, even when carried out in mid-ocean, may contain coastal organisms from the hull fouling of the preceding vessel. Although this scenario is of low probability it cannot be excluded completely. Harpacticoid copepods are benthic species and their presence in ballast water clearly indicates coastal origin of the water. However, these species can also be found in the sediment of ballast water tanks. A study demonstrated that the numbers of the harpacticoid copepods inside a ballast tank increase during the voyage indicating reproduction may occur [4]. As result, biological sampling for compliance control with D-1 can only deliver data with a limited level of certainty and in case of non-compliance it is indicated that these data are not considered to be "court-proof". Consequently, biotic samplings for D-1 compliance can be put in question in case non-compliance is assumed (Tables 1 and 2).

\subsubsection{Recommendations for compliance control samplings with the Ballast Water Performance Standard (D-2)}

Compliance control with the D-2.1 standard is solely quantitative, thereby ignoring the type of organisms with the exception of selected indicator microbes (D-2.2). It is the numbers of living organisms per size class to document (non-)compliance. As the BWM Convention in Regulation D-2 reads “...Ships conducting Ballast Water Management in accordance with this regulation shall discharge less than 10 viable organisms per $\mathrm{m}^{3}$..." the D-2 standard is understood as discharge standard, which indicates that the most suitable sampling point to prove D-2 compliance is the discharge line of the vessels ballast water system as also recommended in the Guidelines G2, i.e. samples should be taken from the discharge line, as near to the point of discharge as practicable, during ballast water discharge whenever possible.

However, in-tank sampling should not at all be ruled out - the opposite is true. Some vessels (e.g. bulk carriers, tankers) may have upper side wing tanks that are emptied through direct overboard discharge valves rather than through the ballast pumps (Figure 1). In such cases, the Guidelines G2 indicates that in-tank sampling may be an appropriate approach. Further, almost all vessels lack sampling points in their ballast water line. Not to limit compliance control with the D-2 standard only to those vessels with such sampling points we propose to sample the ballast water also intank (Tables 1 and 2). This might be especially critical if a Port State is implementing a risk-based BWM approach according to the BWM Convention. The ballast water may need to be sampled prior to the discharge if there is a suspicion that the ballast water was loaded in an area affected with e.g. unwanted target species, harmful algae or cholera outbreaks and hence represents the highest risk.

\section{DISCUSSION}

Ballast water sampling may be conducted for different aims: to assess the biology and chemistry of ballast water (scientific research); to identify potentially harmful or other organisms carried in ballast water (risk assessment); and, to assess compliance with ballast water management requirements (monitoring and enforcement) which is in focus of this contribution. The ballast water sampling, however, is complex due to dif-

Table 1. Sampling approach for compliance control with ballast water management requirements.

\begin{tabular}{||l|l|l||}
\hline \multicolumn{1}{|c|}{ Sampling purpose } & \multicolumn{1}{|c|}{$\begin{array}{c}\text { Compliance monitoring } \\
\text { D-1 }\end{array}$} & \multicolumn{1}{c|}{$\begin{array}{c}\text { Compliance monitoring } \\
\text { D-2 }\end{array}$} \\
\hline \hline Sampling point & In-tank & At-discharge and/or In-tank \\
\hline Taxonomic coverage & Target taxa (to prove coastal origin of water) & All taxa, indicator microbes and bacteriae \\
\hline Qualitative / Quantitative & Qualitative (to prove coastal origin of water) & $\begin{array}{l}\text { Quantitative for organisms above } 10 \mu \mathrm{m} \\
\text { and qualitative for indicator microbes }\end{array}$ \\
\hline
\end{tabular}

Table 2. Appropriateness of the sample access point for compliance control with ballast water management requirements.

\begin{tabular}{|c|c|c|}
\hline Sampling point & $\begin{array}{l}\text { Compliance monitoring } \\
\text { D-1 }\end{array}$ & $\begin{array}{l}\text { Compliance monitoring } \\
\text { D-2 }\end{array}$ \\
\hline Sounding pipe & $\begin{array}{l}\text { recommended for } \\
\text { abiotic parameters, suitable for target taxa }\end{array}$ & suitable for tanks with direct discharge to sea \\
\hline Manhole & $\begin{array}{l}\text { suitable for } \\
\text { abiotic parameters, target taxa }\end{array}$ & suitable for tanks with direct discharge to sea \\
\hline Ships fire-fighting system & $\begin{array}{l}\text { not recommended, } \\
\text { discharge to sea may occur during sampling }\end{array}$ & $\begin{array}{l}\text { not recommended, unknown negative organ- } \\
\text { ism impact of high pressure in the system }\end{array}$ \\
\hline Ships ballast water line & $\begin{array}{l}\text { not recommended, } \\
\text { discharge to sea occurs during sampling }\end{array}$ & recommended \\
\hline
\end{tabular}




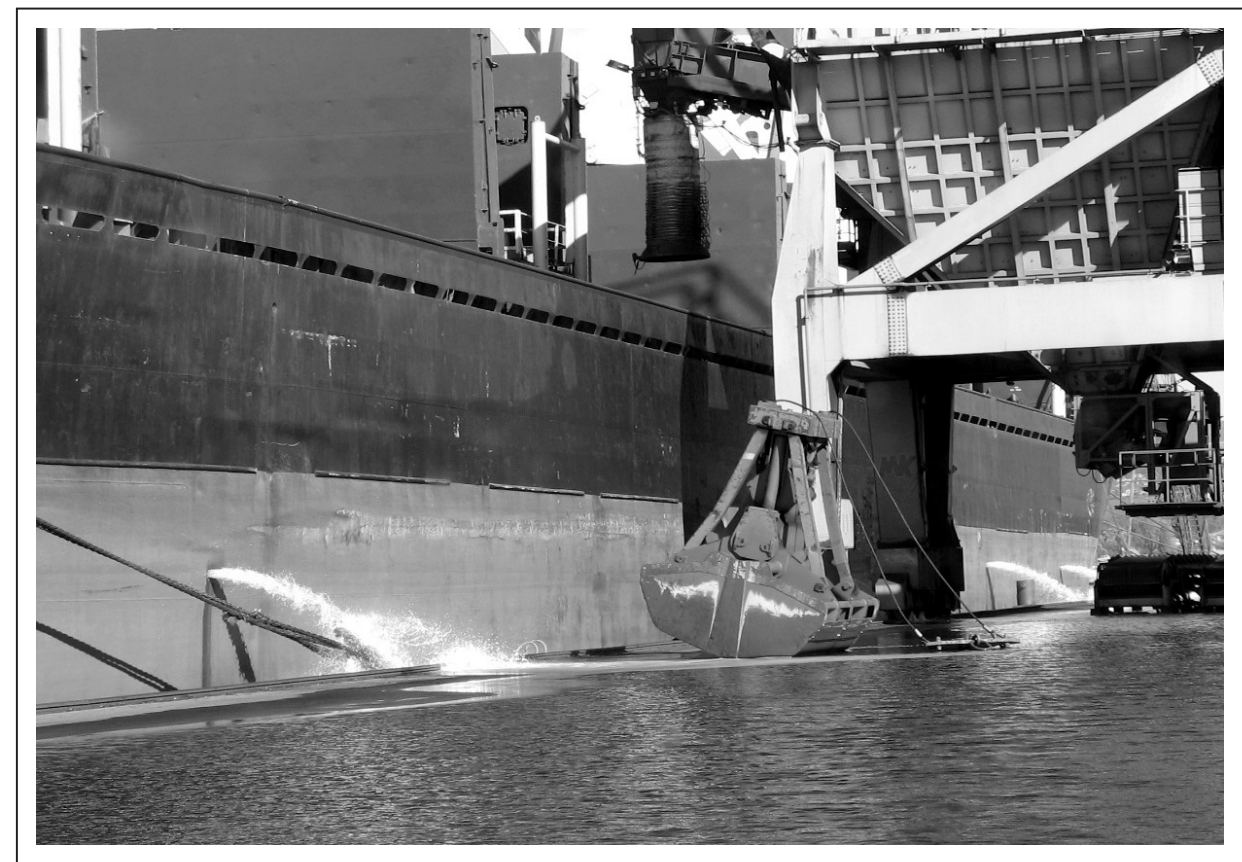

Figure 1 - Discharge of ballast water above the level of the pier from the upper side wing tanks of a bulk-carrier Source: Jure Barovic, with courtesy of the Port of Koper, services for protection of the sea

ferences in organisms' dimensions and behaviour, as well as to differences in ship construction including availability of sampling points. These issues as well as the aims of a ballast water sampling study impact the sampling method selection.

During a Slovenian research study, the use of different ballast water sampling methods was evaluated in the context of risk assessment and ballast water management. The sampling point availability has proven to be a critical issue. The employment of sampling equipment, modified for onboard use, and a flexible approach is needed to allow sampling via different access points. New methods were developed to ease ballast water sampling onboard ships including especially designed equipment for in-tank sampling through sounding pipes, and sampling at the fire-fighting system. Sounding pipe sampling was achieved by the use of an air-driven well pump, a water-column sampler, and a bottom and sediment sampler. Onboard tests have shown that this sampling equipment may be used to sample most target organisms despite some size limitations which may occur according to the opening dimension of the sampling tool. The tests also confirmed that all three water samplers can be safely used on almost all ships, while not disturbing standard ship operations conducted in the port. In addition to their deployment via sounding pipes these specially designed samplers may also be employed via manholes or tank hatches [7, 37].

Sampling using the fire-fighting system is enabled due to the connection between the ballast and firefighting systems on many ships. This sampling approach requires nets to collect samples where the wa- ter exits from the fire-fighting system taps, and requires ships crew assistance to connect the ballast water and fire-fighting systems by operating valves. Possible negative effects of high water pressure on organisms and the fire-fighting piping system should be taken into consideration. Nevertheless, samplings via the fire-fighting systems may offer an additional possibility, especially when no other sampling method can be used.

Provided the sampling point design and technique chosen delivers representative samples, the in-tank sampling represents an assessment of the potential species inoculation, whereas at-discharge sampling represents the realised inoculation. As a result, in-tank sampling may be more appropriate for scientific research and risk assessment with the aim of assessing the ballast biota, while at-discharge sampling is more appropriate for the monitoring of compliance with the ballast water management requirements. However, certain tanks are not discharged through pipe-work onboard, but may use gravity to empty them. In those cases in-tank sampling is the only way to prove compliance with the ballast water management standards. Further, in-tank sampling may also be used for risk assessment, e.g. to prove the presence or absence of target organisms before the ballast water is being discharged.

\subsection{Selection of ballast water sampling equipment}

It was concluded that sampling for zooplankton via the sounding pipes does not result in a representa- 
tive sample of species in the tank as comparisons of sounding pipe and manholes samples from the same tank found that net samples were more diverse [32]. The sounding pipe samples contained $0-60 \%$ of the organisms of a net sample indicating the need to sample ballast tanks via opened manholes. Further, pumps used via open manholes delivered more diverse samples than net samples, therefore pumps may be considered when sampling via manholes [32]. Future ballast water studies should take into account that sampling via sounding pipes is inferior when selecting appropriate sampling techniques. However, frequently manholes cannot be opened due to, e.g. overlaying cargo or cargo operations in the area where the manhole is located, and in these instances the sounding pipe sampling might be the only solution to sample the ballast water at all [31, 37].

For the most appropriate choice of the ballast water sampling method and equipment it should also be decided between a qualitative or quantitative analyses, or both. As the IMO ballast water performance standard (Regulation D-2) refers to organism numbers per size class for the organisms above 10 microns in minimum dimension, thereby ignoring the taxonomic diversity, we propose that for compliance monitoring with the non-bacteriae BWM Convention standards only quantitative sampling methods should be used.

The sampling programs usually include sampling of a number of various types of ships in a port. After having selected a ship according to the sampling program (e.g. ships originating from certain source regions that presumably will discharge ballast water in the port), ballast tanks are to be selected for sampling. Sampling access plays a crucial role and actually determines if the ballast water is available for sampling. Therefore, the sampling equipment, which allows access to various sampling points, is in most cases crucial to obtain a sample. In case different methods are used intercalibration between methods may be needed to allow for the comparison of results.

One key problem remains with at-discharge sampling options and this is that compliance or non-compliance can in this scenario only be proven while the ballast water is being pumped overboard. Consequently, the potentially non-compliant ballast water may already have been released before it is clear whether or not it is in compliance with the BWM Convention standards. Should e.g. a risk assessment result in the identification of high-risk ballast water the in-line sampling during discharge should be avoided, but in-tank sampling should be undertaken to assess compliance. Given this, the sharing of compliance information between Parties, specifically the next port of call, to aid an early identification of potentially non-compliant vessels is imperative. Also, in cases where non-compliant vessels revisit the port, additional ballast water management measures may be imposed.

\section{CONCLUSIONS}

Ballast water sampling until now was dealt with at different national, regional and global levels for different purposes. However, many issues were identified which impact representative ballast water sampling, but there is still no commonly agreed methodology or approach.

In routine ballast tank studies the logistical and technical considerations such as access to the water via sounding pipes and manholes, tank depth, manhole diameter and design of internal support frame structures within the ballast tanks will also determine which sampling technique may be used.

As there is no uniform ballast water sampling methodology currently established worldwide, the biological results from compliance monitoring of vessels cannot easily be compared without intercalibration experiments. This also has an influence on the compliance control samplings, i.e. without a harmonized sampling approach a certain vessel may be in compliance in one port, but not in another - being an unacceptable situation.

Further, as no single sampling equipment will suit for all purposes and ballast water access points many different methods and sampling equipment have been used by different research programmes. Sample representativeness is of key importance and currently we lack answers to some of the most important questions:

- the most suitable sample access point to deliver representative samples,

- the frequency of the sampling events, and

- the minimum water volume to be sampled, etc.

If the sampling is to document non-compliance (i.e. violation of the ballast water discharge standard), much less onerous sampling requirements are posed to the port state as a demonstration that an explicit value is exceeded. For example, if a sample of 100 I contained 20 living organisms greater than $50 \mu \mathrm{m}$ in minimum dimension, then it can be assumed that more than 10 organisms were present in that metric tonne, and therefore the vessel was in violation under an instantaneous standard (see Regulation D-2 above).

Full recovery of organisms contained in ballast tanks may remain impossible, indicating that results of ballast water sampling studies may well underestimate the actual number of organisms and species being present in the ballast tank. Combinations of the more efficient sampling equipment are likely to reveal a greater range of taxa than any single method. Larger organisms may also be sampled by the use of different collecting methods, such as light traps or baited traps [36]. However, this approach is time-consuming and requires installation of traps prior to sampling which is impossible for compliance control sampling. 
For compliance control we suggest that samples should either be taken during discharge, i.e. from the ballast water discharge line after the pump or directly from the tank. The shortcomings of the discharge line samplings include that a sampling point needs to be installed in the ballast water discharge line somewhere in the engine room. Consequently, large volumes of water may need to be filtered and possibly be dumped in the bilge water system, if water discharge after sampling is not adequately provided otherwise. On certain vessels this may be critical, but we assume that, with today's technologies, this approach delivers the most accurate results of organisms being discharged in ballast water from a vessel as a sidestream of all ballast water being discharged is sampled. By doing so the heterogeneously distributed organisms in the ballast water will most likely be sampled which may not be the case in any other point source sampling method. However, and as stated above, in-tank compliance control sampling may be more appropriate as the in-line approach can only be undertaken during the discharge of the ballast water and should high-risk organisms be suspected in the water they will enter the port during the in-line sampling process which should be avoided. Therefore, in-tank sampling is more appropriate in these cases.

As non-compliance with the ballast water discharge standards of the BWM Convention may have legal implications, we recommend that improved sampling methods should be developed and tested for their representativeness, including onboard performance tests.

\section{ACKNOWLEDGEMENTS}

Ballast water sampling experience referred to in this manuscript was generated during the following research projects (a) the "German Ballast Water Study" funded by the German Federal Environment Agency, Berlin, Germany, (b) the EU-funded Concerted Action "Testing Monitoring Systems for Risk Assessment of Harmful Introductions by Ships to European Waters", Contract No. MAS3-CT97-0111, (c) "Harmful Introductions and Ballast Water Management in the Slovenian Sea", financially supported by the Ministry of Education, Science and Sports of the Republic of Slovenia and the Port of Koper (Luka Koper d.d.), (d) "Decision Model and Control of Ballast Water Management in the Slovenian Sea", financially supported by the Slovenian Research Agency and the Port of Koper (Luka Koper d.d.), and (e) the onboard ballast water sampling voyage "Ship-board ballast water sampling trials to take representative samples for compliance control with the D-2 Standard of the Ballast Water Management Convention" funded by Federal Maritime and Hydrographic Agency, Hamburg, Germany.

\section{Dr. STEPHAN GOLLASCH}

E-mail: sgollasch@aol.com

GoConsult

Grosse Brunnenstrasse 61, 22763 Hamburg, Germany

Dr. MATEJ DAVID

E-mail: matej.david@fpp.uni-lj.si

Univerza v Ljubljani, Fakulteta za pomorstvo in promet

Pot pomorščakov 4, 6320 Portorož, Slovenia

\section{ZUSAMMENFASSUNG}

\section{BEPROBUNGSMETHODEN UND VORGEHENSWEISEN ZUR ÜBERPRÜFUNG VON MASSNAHMEN UND STANDARDS BEZÜGLICH BALLASTWASSER-MANAGEMENT}

Der durch Menschen verursachte Transport von Organismen mit der Schifffahrt, insbesondere per Ballastwasser, erreichte in den letzten Dekaden, wegen der negativen Auswirkungen hervorgerufen durch diese Arten, besondere Beachtung. Die Beprobung von Ballastwasser ist eine wichtige Vorgehensweise um die Einhaltung von Standards zu Ballastwasser-Management zu überprüfen. Die Ballastwasser-Beprobung ist ein sehr komplexer Vorgang, bedingt durch die Vielfalt der potentiell anzutreffenden Arten und deren unterschiedlichem Verhalten sowie durch verschiedene Schiffskonstruktionen was eine unterschiedliche Vorgehensweise zur Probennahme impliziert. Dieses Manuskript diskutiert Methoden zur Ballastwasserbeprobung mit dem Schwerpunkt auf Vorgehensweisen zur Überprüfung von Maßnahmen und Standards bezüglich Ballastwasser-Management im Rahmen der Hafenstaatkontrolle wie vorgegeben im internationalen Übereinkommen zum Management von Ballastwasser und Sedimenten von Schiffen, 2004.

\section{SCHLAGWORTE}

maritimer Transport, Überprüfung von Maßnahmen und Standards, Hafenstaatkontrolle, Ballastwasser-Beprobung, Ballastwasser-Management

\section{LITERATURE}

[1] Carlton, J.T.: 1985: Transoceanic and Interoceanic Dispersal of Coastal Marine Organisms: the Biology of Ballast Water, Oceanographic Marine Biology Annual Review, Vol. 23, 1985, pp. 313-374

[2] Williams, R.J., Griffiths, F.B., Van der Wal, E.J., Kelly, J.: Cargo Vessel Ballast Water as a Vector for the Transport of Nonindigenous Marine Species, Estuarine, Coastal and Shelf Science, Vol. 26, 1988, pp. 409-420

[3] Macdonald, E., Davidson, R.: Ballast Water Project. Fisheries Research Services Report Number 3/97, FRS Marine Laboratory Aberdeen, Scotland, 1997

[4] Gollasch, S., Lenz, J., Dammer, M., Andres, H.G.: Survival of Tropical Ballast Water Organisms During a Cruise from the Indian Ocean to the North Sea, Journal of Plankton Research, Vol. 22, 2000a, pp. 923-937

[5] Gollasch, S., Rosenthal, H., Botnen, H., Hamer, J., Laing, I., Leppäkoski, E., Macdonald, E., Minchin, D., Nauke, M., Olenin, S., Utting, S., Voigt, M., Wallentinus, I.: Fluctuations of Zooplankton Taxa in Ballast 
Water during Short-term and Long-term Ocean-going Voyages, International Revue of Hydrobiology, Vol. 85, 2000b, pp. 597-608

[6] Olenin, S., Gollasch, S., Jonusas, S., Rimkute, I.: Enroute Investigation of Plankton in Ballast Water on Ship's Voyage from the Baltic Sea to the Open Atlantic Coast of Europe, International Revue of Hydrobiology, Vol. 85, 2000, pp. 577-596

[7] David, M., Gollasch, S., Cabrini, M., Perkovic, M., Bošnjak, D., Virgilio, D.: Results from the First Ballast Water Sampling Study in the Mediterranean Sea - the Port of Koper study, Marine Pollution Bulletin, Vol. 54 2007, pp. 53-65

[8] Flagella, M.M., Verlaque M., Soria A., Buia M.C.: Macroalgal Survival in Ballast Water Tanks, Marine Pollution Bulletin, Vol. 54, No. 9, 2007, pp. 1395-1401

[9] Gollasch, S.: The Importance of Ship Hull Fouling as a Vector of Species Introductions into the North Sea, Biofouling, Vol. 18, 2002, pp.105-121

[10] Coutts, A.D.M., Kirrily, M.M., Hewitt, C.L.: Ships' Seachests: an Overlooked Transfer Mechanism for Nonindigenous Marine Species?, Marine Pollution Bulletin, Vol. 46, 2003, pp. 1504-1515

[11] Mineur F., Johnson M.P., Maggs C.A., Stengenga H.: Hull Fouling on Commercial Ships as a Vector of Macroalgal Introduction, Marine Biology, Vol. 151, 2007, pp. $1229-1307$

[12] Carlton, J.T., Geller, J.B.: Ecological Roulette: the Global Transport and Invasion of Nonindigenous Marine Organisms, Science, Vol. 261, 1993, pp. 78-82

[13] Hallegraeff, G.M.: A Review of Harmful Algal Blooms and their Apparent Global Increase, Phycologia, Vol. 32, No. 2, 1993, pp. 79-99

[14] Hay, C., Handley, S., Dogdshun, T., Taylor, M., Gibbs, W.: Cawthron's Ballast Water Research Programme Final Report 1996-97, Cawthron Institute, Cawthron Report No. 417, 1997

[15] Gollasch, S.: Removal of Barriers to the Effective Implementation of Ballast Water Control and Management Measures in Developing Countries, International Maritime Orgsanization (IMO), London, United Kingdom, 1998

[16] Ruiz, G.M., Rawlings, T.K., Dobbs, F.C., Drake, L.A., Mullady, T., Huq, A., Colwell, R.R.: Global Spread of Microorganisms by Ships - Ballast Water Discharged from Vessels Harbours a Cocktail of Potential Pathogens, Nature, Vol. 408, 2000, pp. 49-50

[17] Wonham M.J., Walton W.C., Ruiz G.M., Frese A.M., Galil B.S.: Going to the Source: Role of the Invasion Pathway in Determining Potential Invaders, Marine Ecology Progress Series, Vol. 215, 2001, pp. 1-12

[18] Murphy, K.R., Ritz, D., Hewitt, C.L.: Heterogeneous Zooplankton Distribution in a Ship's Ballast Tanks, Journal of Plankton Research, Vol. 24, No. 7, 2002, pp. 729734

[19] Endresen, Ø., Behrens, H.L., Brynestad, S., Andersen, A.B., Skjong, R.: Challenges in Global Ballast Water Management, Marine Pollution Bulletin, Vol. 48, 2004, pp. 615-623

[20] IMO/MEPC: Harmful Aquatic Organisms in Ballast Water. Report of the Ballast Water Working Group. MEPC 42/8, International Maritime Organization, 1998
[21] Carlton, J.T.: Introduced Species in U.S. Coastal Waters: Environmental Impacts and Management Priorities, Pew Oceans Commission, Arlington, Virginia, USA, 2001

[22] Gollasch, S., Macdonald, E., Belson, S., Botnen, H., Christensen, J., Hamer, J., Houvenaghel, G., Jelmert, A., Lucas, I., Masson, D., McCollin, T., Olenin, S., Persson, A., Wallentinus, I., Wetsteyn, B., Wittling, T.: Invasive Aquatic Species of Europe: Distribution, Impacts and Management, Kluwer Academic Publishers, Dordrecht, The Netherlands, 2002

[23] Nellemann, C., Hain, S., Alder, J. (eds): Dead Water Merging of Climate Change with Pollution, Over-harvest, and Infestations in the World's Fishing Grounds, United Nations Environment Programme, GRID-Arendal, Norway, 2008.

[24] Kettunen, M., Genovesi, P., Gollasch, S., Pagad, S., Starfinger, U., ten Brink, P., Shine, C.: Technical Support to EU Strategy on Invasive Species (IAS) - Assessment of the Impacts of IAS in Europe and the EU. Institute for European Environmental Policy (IEEP), Brussels, Belgium, 2008

[25] Vila, M., Basnou, C., Pyšek, P., Josefsson, M., Genovesi, P., Gollasch, S., Nentwig, W., Olenin, S., Roques, A., Roy, D., Hulme, P.E., DAISIE partners: How Well Do We Understand the Impacts of Alien Species on Ecosystem Services? A pan-European cross-taxa assessment, Frontiers in Ecology and the Environment, 2009a, 12 $\mathrm{pp}$.

[26] Vila, M., Basnou, C., Gollasch, S., Josefsson, M., Pergl, J., Scalera, R.: Handbook of Alien Species in Europe, Invading Nature: Springer Series in Invasion Ecology 3. Springer Science + Business Media B.V., 2009b

[27] Medcof, J.C.: Living Marine Animals in a Ships' Ballast Water, Proceedings National Shellfish Association, Vol. 65, 1975, pp. 54-55

[28] Hallegraeff, G.M., Bloch, C.J.: Transport of Toxic Dinoflagellate Cysts via Ship's Ballast Water, Marine Pollution Bulletin, Vol. 22, 1991, pp. 27-30

[29] McCarthy, S.A., Khambaty, F.M.: International Dissemination of Epidemic Vibrio cholerae by Cargo Ship Ballast and Other Non-potable Waters, Applied Environmental Microbiology, Vol. 60, 1994, pp. 2597-2601

[30] Carlton, J.T., Reid, D.M., van Leeuwen, H.: Shipping Study: The Role of Shipping in the Introduction of Nonindigenous Aquatic Organisms to the Coastal Waters of the United States (others than the Great Lakes) and an Analysis of Control Options, National Sea Grant College Programme, USA, 1995

[31] Gollasch, S.: Untersuchungen des Arteintrages durch den internationalen Schiffsverkehr unter besonderer Berücksichtigung nichtheimischer Arten, Ph.D. thesis, University of Hamburg, Germany (Verlag Dr. Kovac), 1996

[32] Sutton, C.A., Murphy, K., Martin, R.B., Hewitt, C.L.: A Review and Evaluation of Ballast Water Sampling Protocols, Centre for Research on Introduced Marine Pests (CRIMP), Technical report number 18, Hobart, Tasmania, 1998

[33] Oemcke, D., van Leeuven, J.: Chemical and Physical Characteristics of Ballast Water: Implications for Treatment Processes and Sampling Methods, CRC Reef Research, Technical Report No. 23, 1998 
[34] Macdonald, E.M.: Dinoflagellate Resting Cysts and Ballast Water Discharges in Scottish Ports, ICES Cooperative Research Report 224, Copenhagen, Denmark, 1998

[35] Lenz, J., Andres, H.-G., Gollasch, S., Dammer, M.: Einschleppung fremder Organismen in Nord- und Ostsee: Untersuchungen zum ökologischen Gefahrenpotential durch den Schiffsverkehr, Umweltbundesamt, Berlin, Texte 5, Berlin, Germany, 2000

[36] Rosenthal, H., Gollasch, S., Voigt, M. (eds.): Testing Monitoring Systems for Risk Assessment of Harmful Introductions by Ships to European Waters, EU Concerted Action, Final Report, Kiel, Germany, 2000

[37] David, M., Perkovic, M.: Ballast Water Sampling as a Critical Component of Biological Invasions Risk Management, Marine Pollution Bulletin, Vol. 49, 2004, pp. 313-318

[38] IMO/BLG: Results of an Onboard Ballast Water Sampling Study and Initial Considerations on How to Take Representative Samples for Compliance Control with the D-2 Standard of the Ballast Water Management Convention, BLG14/INF.6, International Maritime Organization, London, United Kingdom, 2010
[39] David, M., Gollasch, S., Hewitt, C.L.: Global Marine Transport and Ballast Water Management - Issues and Solutions, Invading Nature - Springer Series in Invasion Ecology, Dordrecht, The Netherlands, in prep.

[40] Gollasch, S., Rosenthal, H., Botnen, H., Crncevic, M., Gilbert, M., Hamer, J., Hülsmann, N., Mauro, C., McCann, L., Minchin, D., Öztürk, B., Robertson, M., Sutton, C., Villac, M.C.: Species Richness and Invasion Vectors: Sampling Techniques and Biases, Biological Invasions, Vol. 5, 2003, pp. 365-377

[41] IMO: Guidelines for Ballast Water Sampling (G2), IMO Resolution MEPC.173(58), International Maritime Organization, London, United Kingdom, 2008

[42] Murphy, K.R., Field, M.P., Waite, T.D., Ruiz, G.M.: Trace Elements in Ships' Ballast Water as Tracers of Midocean Exchange, Science of the total Environment, Vol. 393, 2008, pp. 11-26

[43] Gollasch, S., David, M.: Recommendations How to Take a Representative Ballast Water Sample, Emerging Ballast Water Management Systems, IMO-WMU Research and Development Forum, Malmö, Sweden, January 2010 